\title{
SISTEM INFORMASI PENGERJAAN PROYEK BERBASIS WEB MENGGUNAKAN METODE RAPID APPLICATION DEVELOPMENT
}

\author{
Web-Based Project Work Information System Using Rapid Application Development \\ Method \\ Oky Irnawati ${ }^{1}$ \\ ${ }^{\text {I}}$ Program Studi Teknik Elektro, Fakultas Teknik dan Informatika, Universitas Bina Sarana Informatika, \\ Indonesia \\ e-mail: ${ }^{1}$ oky.okt@bsi.ac.id
}

\begin{abstract}
Abstrak
Penerapan teknologi informasi dalam mengelola penerimaan pengerjaan proyek sangat dibutuhkan untuk meningkatkan performa kerja sehingga perusahaan dapat meningkatkan daya saing. Permasalahan yang ditimbulkan dengan menggunakan sistem manual dalam mengelola penerimaan proyek yang dirasakan PT. Daya Eka seperti pencarian history pekerjaan yang memakan waktu, kesulitan dalam proses monitoring pekerjaan proyek dan seringnya terjadi kesalahan dalam pembuatan invoice akibat data yang duplikat. Membangun sistem informasi yang terkomputerisasi berbasis web dapat menjadi solusi permasalahan terkait sistem penerimaan pengerjaan proyek tersebut. Pemilihan metode rapid application development dianggap paling tepat untuk membangun sistem terkomputerisasi dalam waktu singkat. Tahapan yang dikerjakan meliputi analisa kebutuhan, desain sistem dengan menggunakan UML dalam penggambaran software architecture yaitu dengan membuat use case diagram dan activity diagram serta ERD dalam pembuatan tabel, atribut dan relasi yang dibutuhkan untuk membangun sebuah database, konstruksi berupa pembuatan user interface, dan pengujian. Perubahan sistem yang semula dikerjakan secara manual menjadi terkomputerisasi membawa manfaat diantaranya memberikan kemudahan dalam proses monitoring dan pencarian history pengerjaan proyek, menghilangkan duplikat dan meminimalisir kesalahan pembuatan invoice, meningkatkan kecepatan dan efisiensi penerimaan pengerjaan proyek sehingga performa kerja dapat ditingkatkan.
\end{abstract}

Kata kunci-Sistem Informasi Berbasis Web, Pengerjaan Proyek, Rapid Application Development

\begin{abstract}
The application of information technology in managing the acceptance of project work is needed to improve work performance so that companies can increase competitiveness. Problems caused by using a manual system in managing project acceptance felt by PT. Daya Eka such as searching for work history which takes time, difficulties in monitoring project work processes and frequent errors in making invoices due to duplicate data. Building a web-based computerized information system can be a solution to problems related to the project acceptance system. The selection of the rapid application development method is considered the most appropriate for building a computerized system in a short time. The stages involved include requirements analysis, system design using UML in describing software architecture, namely by making use case diagrams and activity diagrams and ERD in making tables, attributes and relationships needed to build a database, construction in the form of making user interfaces, and testing. Changes to the system that were originally done manually to become computerized bring benefits including providing convenience in the process of monitoring and searching project work history, eliminating duplicates and minimizing invoice creation errors, increasing the speed and efficiency of project acceptance so that work performance can be improved.
\end{abstract}

Keywords - Web-Based Information System, Project Work, Rapid Application Development

Informasi Artikel:

Submitted: September 2021, Accepted: September 2021, Published: November 2021

ISSN: 2685-4902 (media online), Website: http://jurnal.umus.ac.id/index.php/intech 


\section{PENDAHULUAN}

Perkembangan teknologi dalam bidang sistem informasi membawa dampak yang baik pada berbagai bidang usaha termasuk usaha dibidang jasa [1]. Perusahaan bidang jasa memerlukan teknologi informasi untuk meningkatkan kualitas performa kerja sehingga dapat bersaing dengan perusahaan lainnya. Beberapa manfaat penggunaan teknologi informasi diantaranya memudahkan proses pengerjaan, memiliki kecepatan dan ketepatan dalam menyajikan informasi yang relevan untuk pengambilan keputusan, sehingga perusahaan dapat meningkatkan produktivitasnya [2]. Namun demikian masih banyak perusahaan yang belum menerapkan teknologi informasi dalam proses bisnisnya. Hal ini bisa dikarenakan kurangnya pengetahuan mengenai teknologi informasi maupun kurangnya sumber daya manusia yang kompeten dalam bidang teknologi informasi.

PT. Daya Eka yang merupakan perusahaan vendor di bidang jasa telekomunikasi menangani pemasangan perangkat baru, gangguan dan mutasi atau pemindahan perangkat. Dalam proses bisnisnya perusahaan tersebut menggunakan sistem manual menggunakan pencatatan melalui microsoft excel mulai dari penerimaan pekerjaan harian, proses pengerjaan proyek dan monitoring progress pengerjaan proyek serta pembuatan invoice. Permasalahan yang sering terjadi dikarenakan sistem manual tersebut adalah lamanya pencarian data history pekerjaan, kesulitan monitoring progress pengerjaan, data pengerjaan proyek yang duplikat dan kesalahan pembuatan invoice. Hal-hal tersebut dapat menurunkan kualitas performa kerja dan membawa dampak yang merugikan bagi perusahaan.

Oleh karena itu diperlukan perubahan sistem yang semula manual menjadi terkomputerisasi sebagai solusi dari permasalahan yang ada. Penerapan sistem terkomputerisasi ini diharapkan akan membantu proses bisnis perusahaan menjadi lebih cepat, data yang perlu ditampilkan lebih akurat, memudahkan monitoring pekerjaan serta menghilangkan kesalahan terutama dalam pembuatan invoice.

Berdasarkan pemaparan permasalahan yang terjadi pada PT. Daya Eka maka diperlukan Perancangan Sistem Informasi Pengerjaan Proyek Berbasis Web Menggunakan Metode Rapid Application Development (RAD). Tujuannya untuk memudahkan monitoring pekerjaan, menampilkan data secara cepat dan akurat saat pencarian history pengerjaan proyek, menghilangkan kesalahan pembuatan invoice dan meningkatkan performa kerja dalam penanganan proyek. Untuk mencapai tujuannya, maka diperlukan pemilihan model yang tepat dalam penerapan suatu sistem informasi. Metode RAD dipilih karena lebih tepat untuk memenuhi permintaan pembuatan sistem terkomputerisasi dengan waktu yang singkat. Metode ini menekankan pada kebutuhan user melalui masukan langsung sehingga dapat memperkecil kesalahan dan aplikasi yang dihasilkan akan sesuai dengan kebutuhan user [3][4].

Beberapa penelitian mengenai pengembangan sistem informasi baik dalam kasus yang sama yaitu mengenai penanganan pekerjaan maupun penggunaan metode RAD sebagai bahan referensi diantaranya penelitian mengenai perancangan aplikasi monitoring penerimaan dan pelaksanaan proyek berbasis web menggunakan metode prototyping menghasilkan solusi dengan mengubah sistem yang sebelumnya manual menjadi terkomputerisasi untuk pencatatan penerimaan proyek, pekerjaan pembuatan pesanan, pembuatan berita acara dan faktur menjadi efektif dan efisien, mempermudah perusahaan dalam melakukan perhitungan revenue, membantu karyawan dalam membuat berita acara dan invoice dan mempermudah pimpinan dalam melakukan monitoring progres pekerjaan [5]. Penelitian mengenai perancangan sistem informasi work order dengan metode iteratif menggunakan framework codeigniter menghasilkan solusi permasalahan sebelumnya seperti informasi detail dari work order yaitu status, lama pengerjaan, siapa yang mengerjakannya serta pembuatan laporan yang lambat dan kurang akurat dikarenakan sistem yang dikerjakan secara manual. Perancangan sistem dengan pemodelan UML dan pengembangan perangkat lunak dengan metode iterative menggunakan 
database yang terintegrasi untuk memudahkan proses pengelolaan data sehingga informasi yang dibutuhkan dan proses pembuatan laporan menjadi lebih cepat, lengkap dan tepat [6]. Penelitian mengenai penerapan metode rapid application development untuk perancangan sistem informasi penagihan piutang premi asuransi mengatasi permasalahan penagihan asuransi ke nasabah dengan memilih metode RAD karena mempunyai kelebihan sistem dibagi menjadi beberapa versi dan fungsi paling penting yang akan diuji sehingga dianggap metode yang paling tepat [7]. Penelitian mengenai penerapan aplikasi program penjualan dan pembelian menggunakan model rapid application development menghasilkan aplikasi program penjualan dan pembelian yang menjadi solusi permasalahan yang ada sehingga kegiatan menjadi efektif dan efisien. Metode RAD digunakan untuk membangun program dikarenakan memiliki kecepatan tinggi dalam pengembangan perangkat lunaknya [8].

\section{METODE PENELITIAN}

Metode penelitian yang penulis gunakan meliputi metode pengumpulan data dan metode pengembangan perangkat lunak.

\section{Metode Pengumpulan Data}

Observasi

Kegiatan pengamatan dilakukan dengan melihat secara langsung proses bisnis terutama dalam proses penerimaan pekerjaan berupa proyek penanganan pemasangan perangkat baru, penanganan gangguan dan mutasi perangkat, pembuatan invoice untuk tagihan setelah penanganan pekerjaan selesai serta monitoring pekerjaan harian yang dilakukan oleh pihak yang berwenang dalam hal ini disebut dispatcher.

Wawancara

Kegiatan tanya jawab juga dilakukan untuk pengumpulan data berhubungan dengan permasalahan yang menjadi tema yaitu sistem pengerjaan proyek dengan pihak yang terlibat yaitu teknisi sebagai pelaksana pengerjaan proyek dan dispatcher sebagai penanggung jawab proyek.

\section{Metode Pengembangan Perangkat Lunak}

Metode pengembangan perangkat lunak yang penulis gunakan adalah metode Rapid Application Development (RAD) yang merupakan adaptasi metode pengembangan perangkat lunak waterfall [9][10].

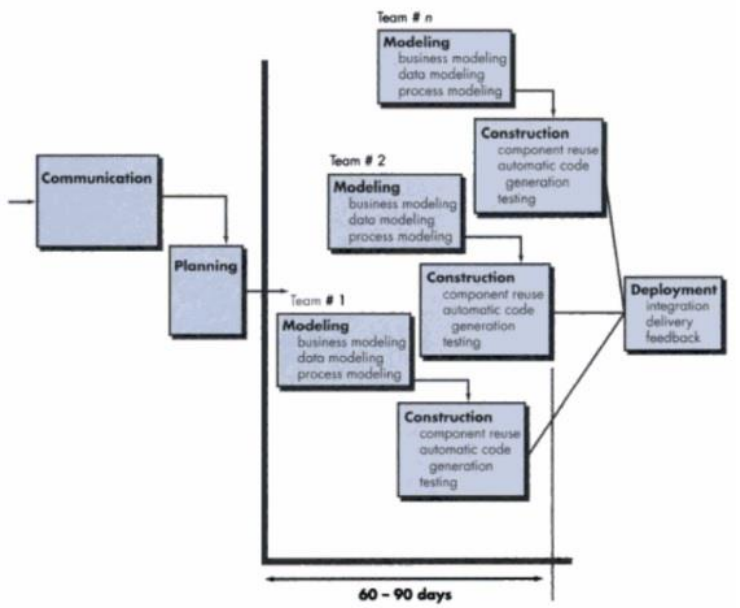

Gambar 1. Ilustrasi RAD Model

Sumber : [10] 
RAD memiliki beberapa tahapan yang dapat disimpulkan yaitu sebagai berikut.

Analisa kebutuhan

Mengidentifikasi kebutuhan pengguna dengan mengumpulkan informasi mengenai permasalahan sistem yang berjalan pada sistem pengerjaan proyek. Kemudian merencanakan perbaikan sistem dengan mengubah sistem menjadi terkomputerisasi sesuai dengan kebutuhan dan keinginan user.

Desain sistem

Merancang sistem yang akan dibangun dengan menggunakan ERD untuk penggambaran tabel, atribut dan relasi yang dibutuhkan. UML untuk menggambarkan pemodelan bisnis dengan mendesain usecase dan pemodelan proses dengan mendesain activity diagram.

Konstruksi

Pembuatan program berbasis web yang dapat mengakomodir kegiatan penerimaan pengerjaan proyek mulai dari pembuatan halaman master data, pembuatan halaman penerimaan proyek, pembuatan invoice, monitoring pengerjaan dan pencarian history pengerjaan proyek. Kemudian mengumpulkan masukan dari pengguna untuk melakukan perubahan sesuai kebutuhan pengguna.

Implementasi

Aplikasi di uji coba dan diterapkan menggantikan sistem yang lama sebagai solusi dari permasalahan sistem yang ada sebelumnya.

\section{HASIL DAN PEMBAHASAN}

\section{Analisa Kebutuhan}

Analisa kebutuhan pengguna dalam sistem informasi pengerjaan proyek meliputi kebutuhan pengguna sebagai admin dan pengguna sebagai dispatcher atau penanggung jawab proyek.

Kebutuhan Admin

a) Admin dapat melakukan login

b) Admin dapat mengelola data master pelanggan

c) Admin dapat mengelola data master jenis paket

d) Admin dapat mengelola data master teknisi

Kebutuhan Dispatcer

a) Pengguna dapat melakukan login

b) Pengguna dapat memonitoring pekerjaan

c) Pengguna dapat menginput pekerjaan baru

d) Pengguna dapat menginput invoice

e) Pengguna dapat melihat history pekerjaan

\section{Desain Sistem}

Desain sistem informasi pengerjaan proyek dibagi menjadi software architecture dan desain database. software architecture digambarkan dengan menggunakan pemodelan UML yaitu dengan menggunakan use case untuk memberikan gambaran interaksi sistem dengan pengguna dan menggunakan activity diagram untuk alur detail aktivitas sistem. Sedangkan desain database digambarkan dengan menggunakan entity relationship diagram (ERD) untuk memberikan gambaran entitas dan relasi antar tabel yang diperlukan.

Use Case Diagram

Pada use case diagram sistem informasi pengerjaan proyek berbasis web tergambar interaksi antara pengguna sistem dengan prosedur sistem. Berikut penggambaran usecasenya sebagai berikut. 


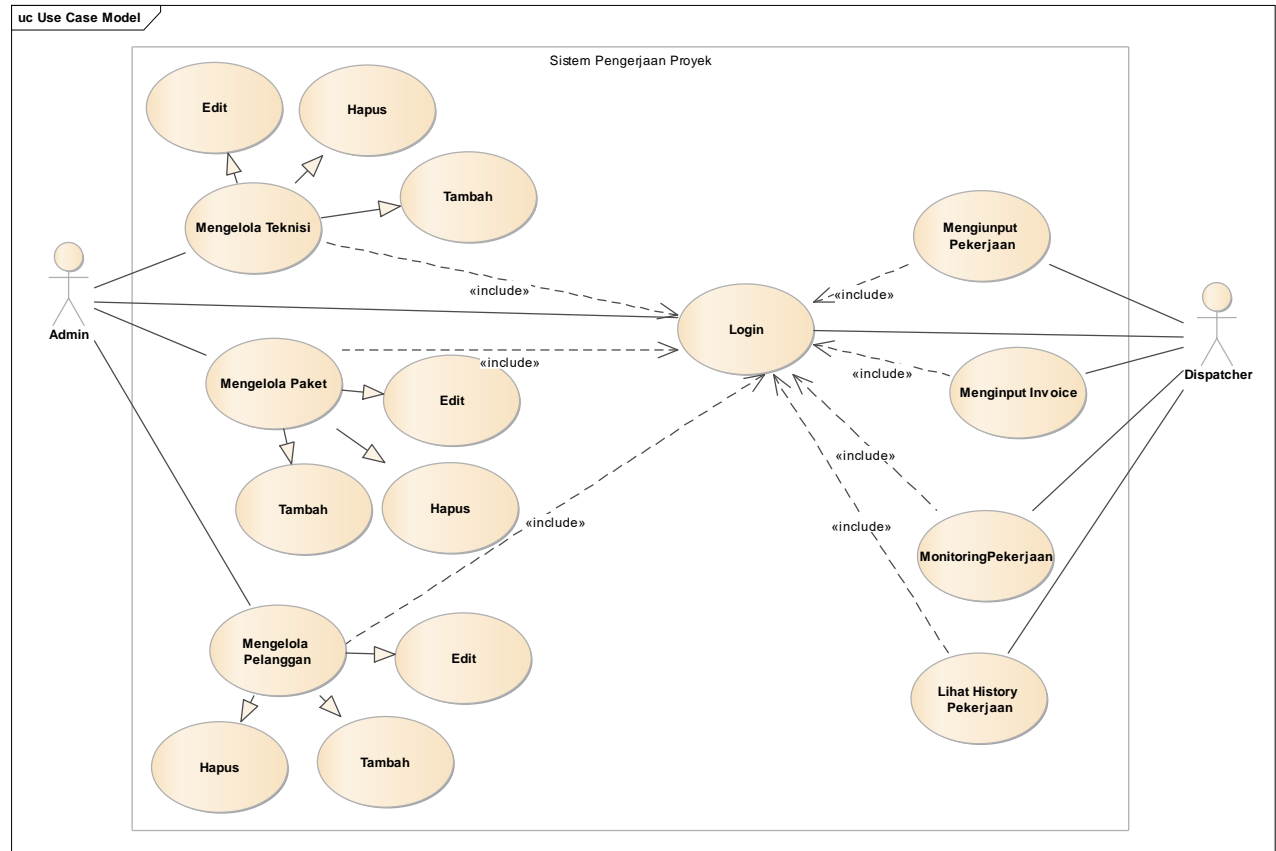

Gambar 2. Use Case Diagram Sistem Informasi Pengerjaan Proyek

Activity Diagram

Pada activity diagram di deskripsikan lebih detail mengenai alur proses sistem. Berikut penggambaran activity diagram sistem informasi pengerjaan proyek yang terbagi menjadi activity diagram admin dan activity diagram dispatcher.

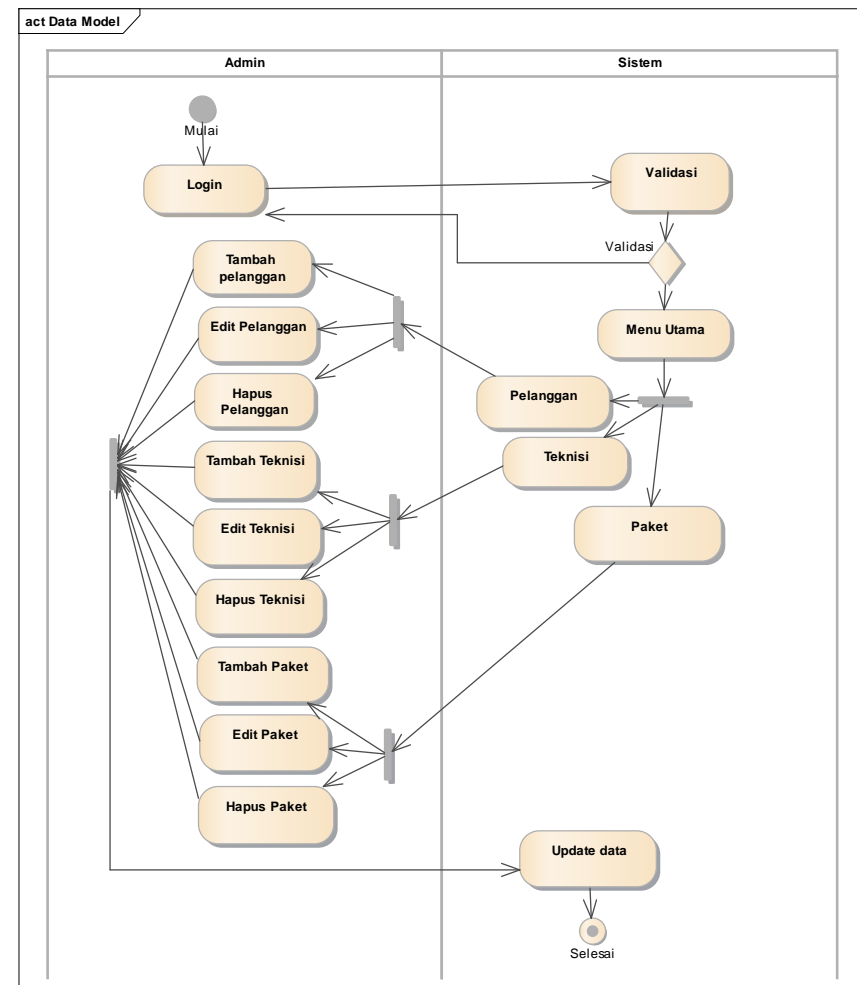

Gambar 3. Activity Diagram Admin Sistem Informasi Pengerjaan Proyek 


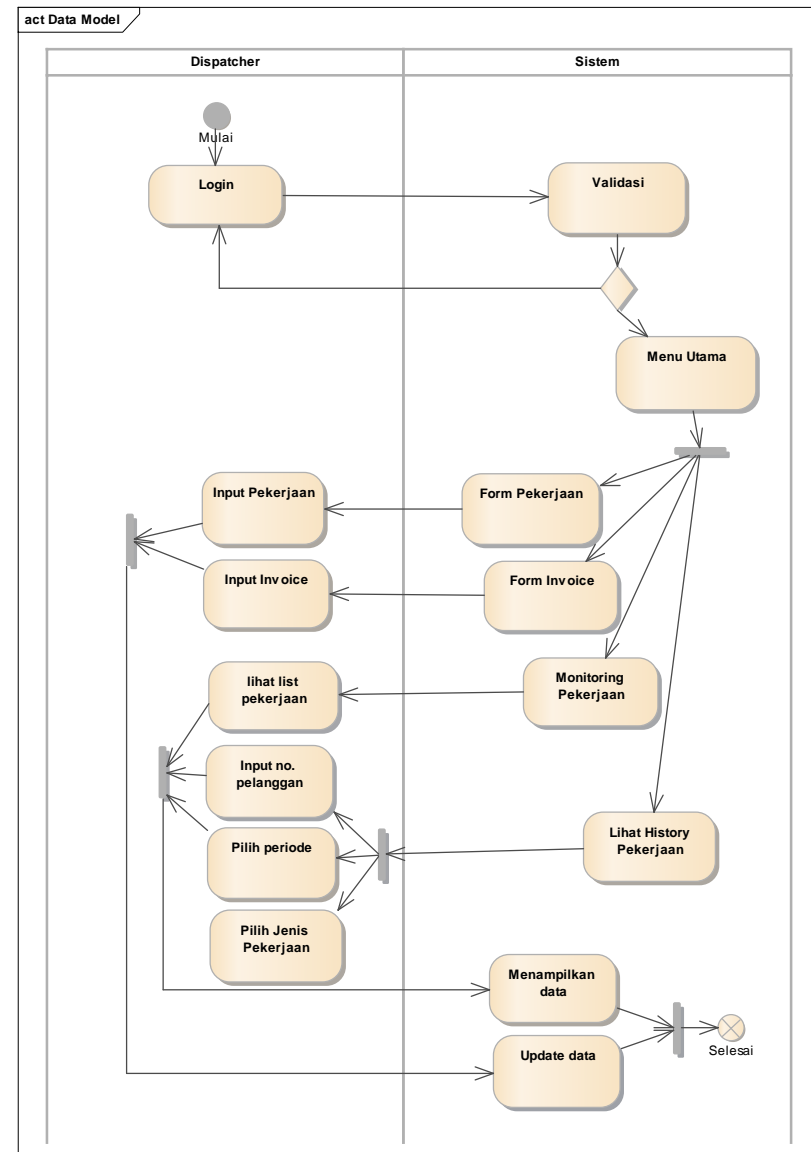

Gambar 4. Activity Diagram Dispatcher Sistem Informasi Pengerjaan Proyek

Entity Relationship Diagram (ERD)

Pada ERD ini di gambarkan table-tabel yang saling berinteraksi disertai atribut yang dimiliki tiap tabel untuk membangun sebuah sistem informasi pengerjaan proyek. Berikut penggambarannya:

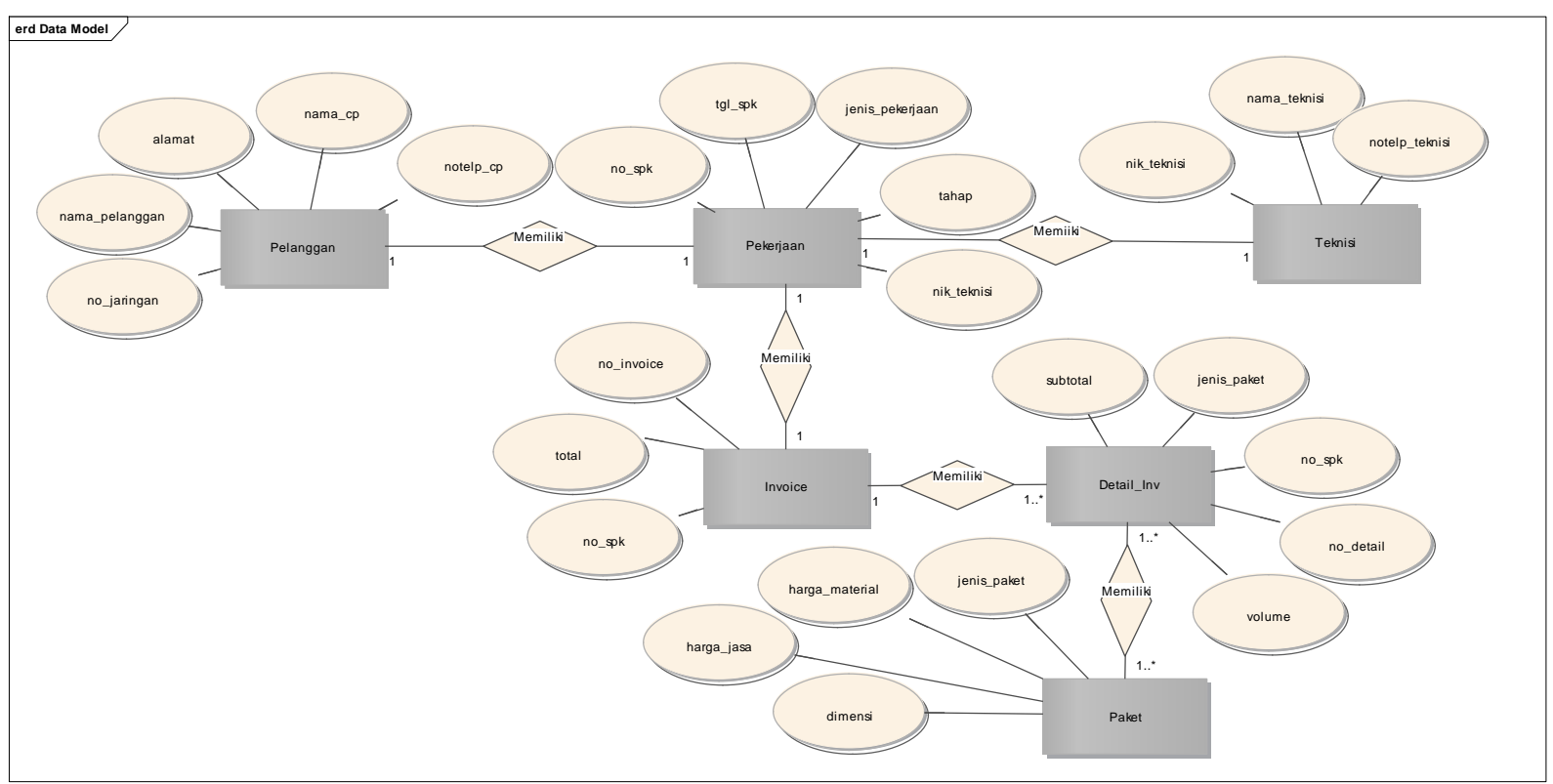

Gambar 5. ERD Sistem Informasi Pengerjaan Proyek 


\section{User Interface}

User interface sistem informasi pengerjaan proyek dibagi atas dua kebutuhan user yaitu admin dan dispatcher.

User Interface Admin

a) Halaman Login

Halaman login digunakan untuk masuk kedalam sistem dengan menginput NIK dan password.

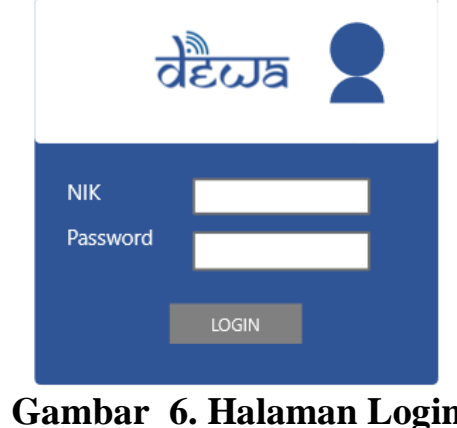

b) Halaman Menu Utama Admin

Menu utama admin berisi sub menu pelanggan, jenis paket dan teknisi yang mengarahkan pada halaman untuk mengelola data-data tersebut.

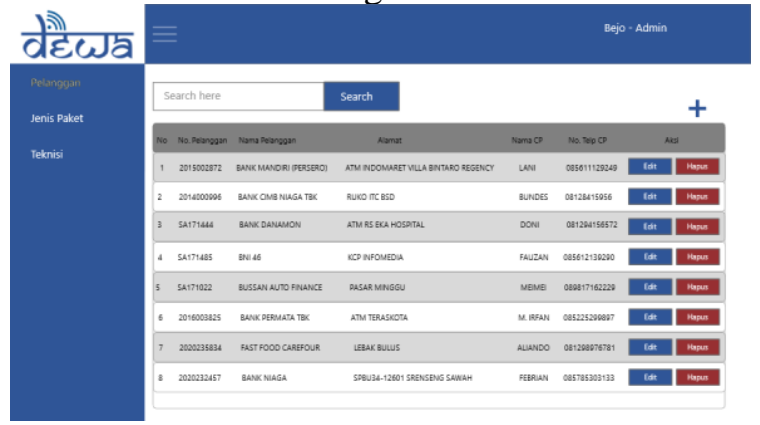

Gambar 7. Menu Utama Admin

c) Halaman Tambah Pelanggan

Halaman ini digunakan untuk menginput data pelanggan baru.

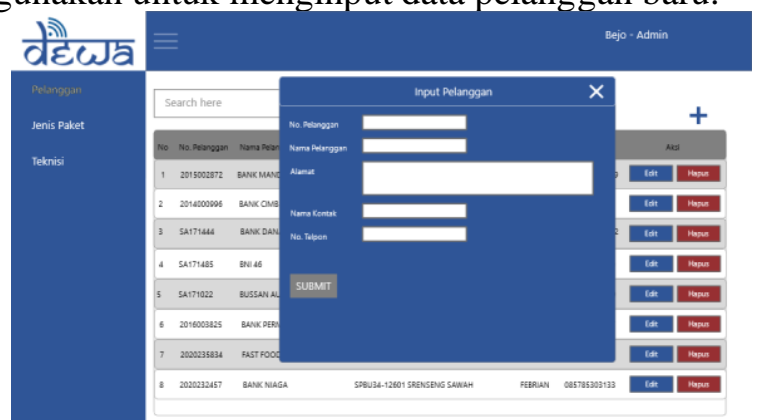

Gambar 8. Halaman Tambah Pelanggan

d) Halaman Edit Pelanggan

Halaman ini digunakan untuk mengedit data pelanggan dengan cara memilih tombol edit pada baris data pelanggan yang ingin di ubah. Jika ingin menghapus data maka dapat dipilih tombol hapus pada baris data pelanggan. 


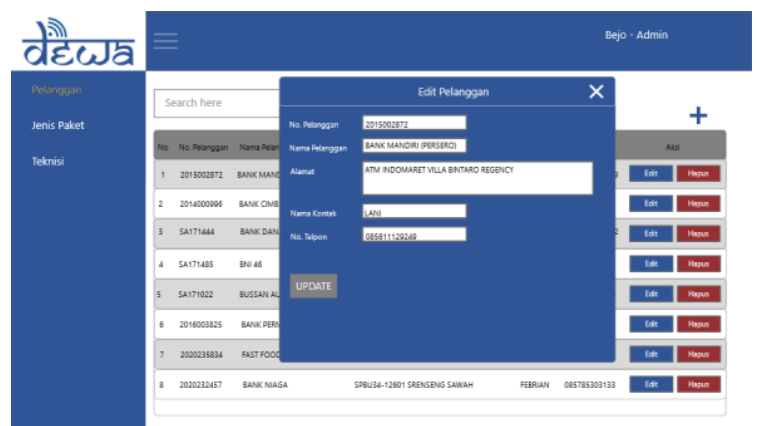

Gambar 9. Halaman Edit Pelanggan

e) Halaman Tambah Jenis Paket

Halaman ini digunakan untuk menginput data jenis paket baru.

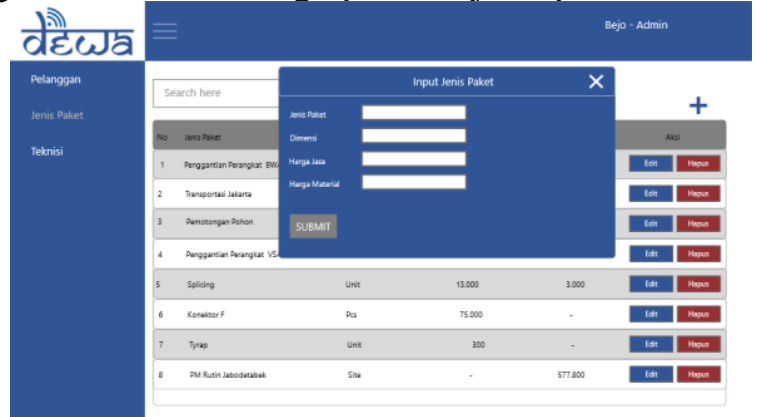

Gambar 10. Halaman Tambah Jenis Paket

f) Halaman Edit Jenis Paket

Halaman ini digunakan untuk mengedit data jenis paket dengan cara memilih tombol edit pada baris data jenis paket yang ingin di ubah. Jika ingin menghapus data maka dapat dipilih tombol hapus pada baris data jenis paket.

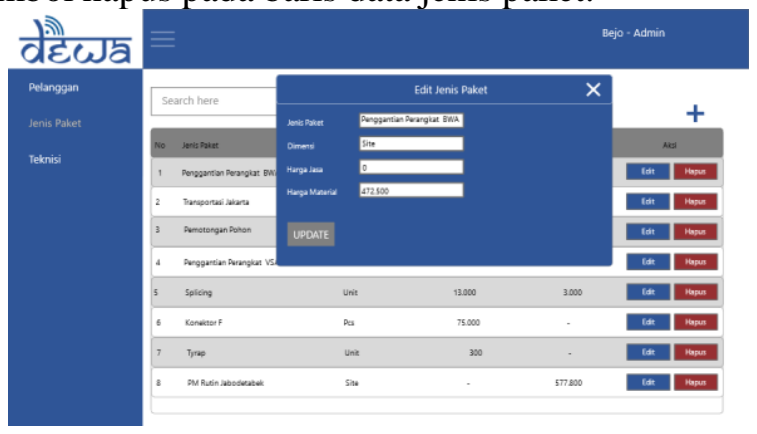

Gambar 11. Halaman Edit Jenis Paket

g) Halaman Tambah Teknisi

Halaman ini digunakan untuk menginput data teknisi baru.

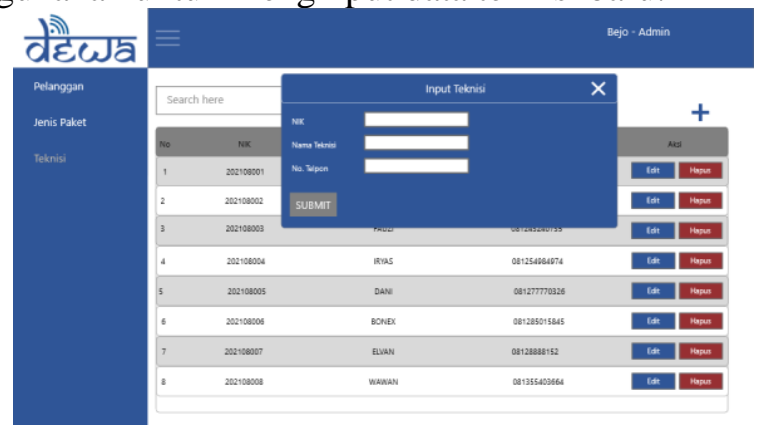

Gambar 12. Halaman Tambah Teknisi 
h) Halaman Edit Teknisi

Halaman ini digunakan untuk mengedit data teknisi dengan cara memilih tombol edit pada baris data teknisi yang ingin di ubah. Jika ingin menghapus data maka dapat dipilih tombol hapus pada baris data teknisi.

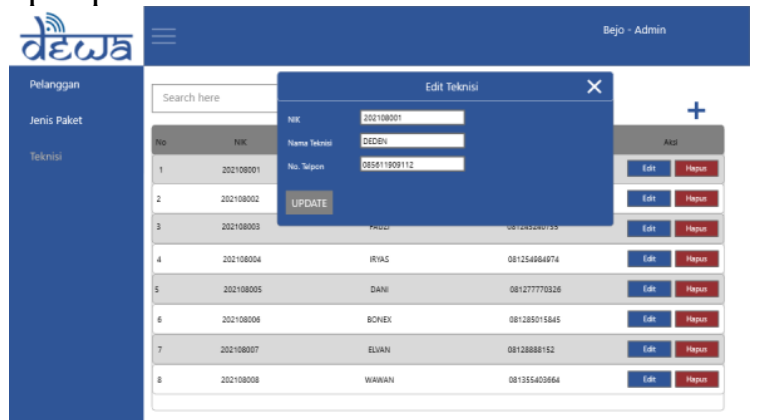

Gambar 13. Halaman Edit Teknisi

User Interface Dispatcher

a) Halaman Monitoring

Halaman ini digunakan dispatcher untuk memonitoring pekerjaan. Status monitoring onproses untuk pekerjaan yang baru diinput, status inv untuk pekerjaan yang telah dibuatkan invoicenya dan status end untuk pekerjaan yang telah menerima pembayaran.

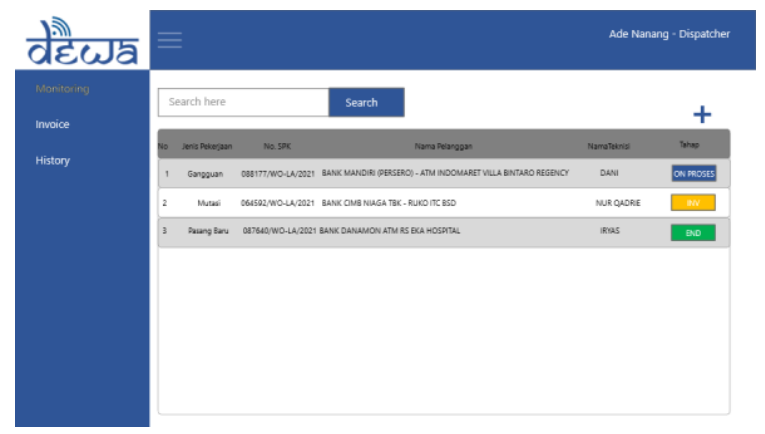

\section{Gambar 14. Halaman Monitoring Dispatcher}

b) Halaman Input Pekerjaan

Halaman ini digunakan untuk menginput pekerjaan baru.

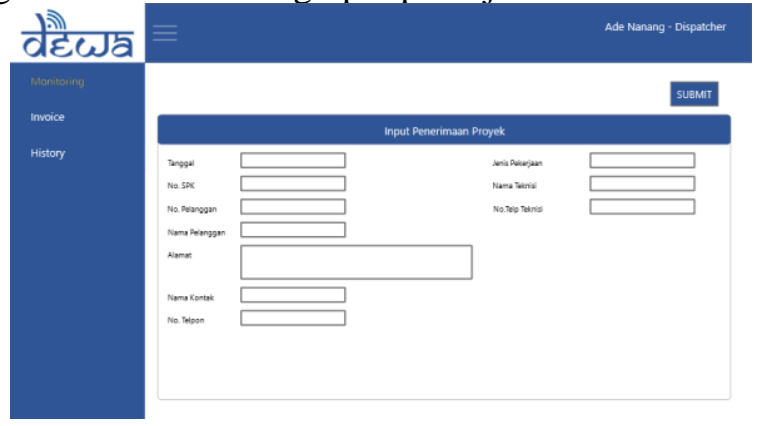

\section{Gambar 15. Halaman Input Pekerjaan}

c) Halaman Input Invoice

Halaman ini digunakan untuk menginput data invoice baru, bisa melalui klik menu invoice maupun klik tombol on proses untuk tiap baris data pekerjaan. 


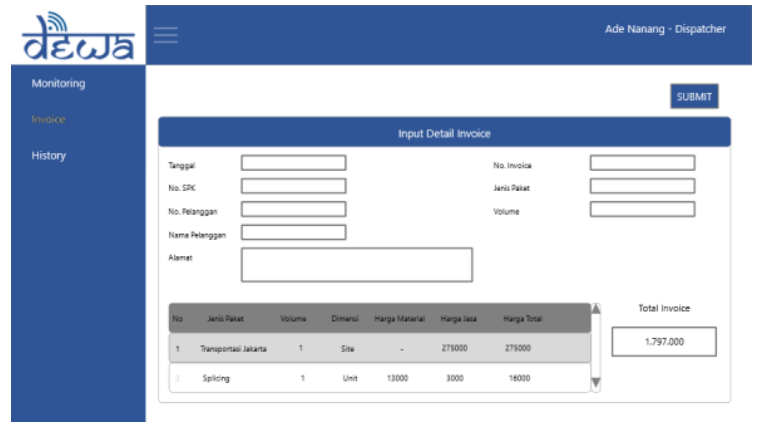

Gambar 16. Halaman Input Invoice

d) Halaman Lihat History Pekerjaan

Halaman ini digunakan dispatcher untuk melihat riwayat pekerjaan dengan filter pencarian tanggal atau nama pelanggan atau jenis pekerjaan.

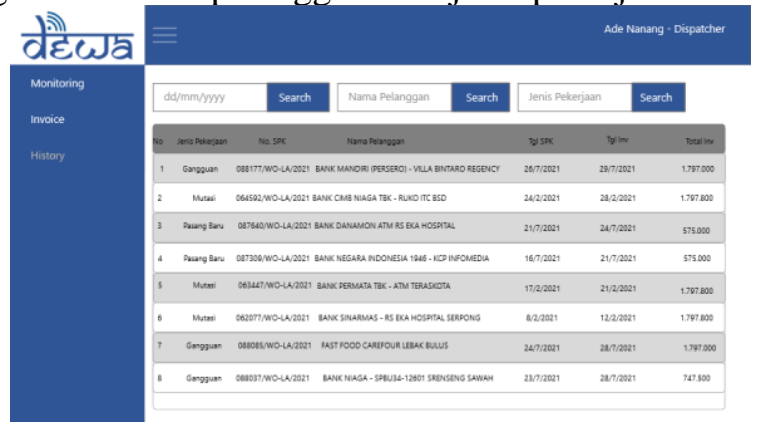

Gambar 17. Halaman Lihat History Pekerjaan

\section{Pengujian Sistem}

Pengujian software dibutuhkan untuk mengetahui apakah sistem dapat digunakan dengan baik dan sistem yang dibangun sudah sesuai dengan keinginan user.

Tabel 1. Pengujian User Interface Admin

\begin{tabular}{ccccccccc}
\hline Partisipan & $\begin{array}{c}\text { Login } \\
\text { admi }\end{array}$ & $\begin{array}{c}\text { Akses } \\
\text { menu }\end{array}$ & $\begin{array}{c}\text { Tambah } \\
\text { pelangga }\end{array}$ & $\begin{array}{c}\text { Edit } \\
\text { pelangga }\end{array}$ & $\begin{array}{c}\text { Tamba } \\
\text { h paket }\end{array}$ & $\begin{array}{c}\text { Edit } \\
\text { pake }\end{array}$ & $\begin{array}{c}\text { Tamba } \\
\text { h }\end{array}$ & $\begin{array}{c}\text { Edit } \\
\text { teknis }\end{array}$ \\
& n & utam & n & n & & t & teknisi & i
\end{tabular}

\begin{tabular}{lcccccccc} 
& & $\mathbf{a}$ & $\sqrt{ }$ & $\sqrt{ }$ & $\sqrt{ }$ & $\sqrt{ }$ & $\sqrt{ }$ & $\sqrt{ }$ \\
\hline Admin 1 & $\sqrt{ }$ & $\sqrt{ }$ & $\sqrt{ }$ & $\sqrt{ }$ & $\sqrt{ }$ & $\sqrt{ }$ & $\sqrt{ }$ & $\sqrt{ }$ \\
\hline Nilai & $100 \%$ & $100 \%$ & $100 \%$ & $100 \%$ & $100 \%$ & $100 \%$ & $100 \%$ & $100 \%$
\end{tabular}
kesuksesa

n

Tabel 2. Pengujian User Interface Dispatcher

\begin{tabular}{lcccccc}
\hline Partisipan & $\begin{array}{c}\text { Login } \\
\text { dispatcher }\end{array}$ & $\begin{array}{c}\text { Akses } \\
\text { menu } \\
\text { utama }\end{array}$ & $\begin{array}{c}\text { Input } \\
\text { pekerjaan }\end{array}$ & $\begin{array}{c}\text { Input } \\
\text { invoice }\end{array}$ & $\begin{array}{c}\text { Monitoring } \\
\text { pekerjaan }\end{array}$ & $\begin{array}{c}\text { Lihat } \\
\text { history }\end{array}$ \\
\hline dispatcher 1 & $\sqrt{ }$ & $\sqrt{ }$ & $\sqrt{ }$ & $\sqrt{ }$ & $\sqrt{ }$ & $\sqrt{ }$ \\
\hline dispatcher 2 & $\sqrt{ }$ & $\sqrt{ }$ & $\sqrt{ }$ & $\sqrt{ }$ & $\sqrt{ }$ & $\sqrt{ }$ \\
\hline dispatcher 3 & $\sqrt{ }$ & $\sqrt{ }$ & $\sqrt{ }$ & $\sqrt{ }$ & $\sqrt{ }$ & $\sqrt{ }$ \\
\hline dispatcher 4 & $\sqrt{ }$ & $\sqrt{ }$ & $\sqrt{ }$ & $\sqrt{ }$ & $\sqrt{ }$ & $\sqrt{ }$ \\
\hline $\begin{array}{l}\text { Nilai } \\
\text { kesuksesan }\end{array}$ & $100 \%$ & $100 \%$ & $100 \%$ & $100 \%$ & $100 \%$ & $100 \%$ \\
\hline
\end{tabular}




\section{KESIMPULAN}

Sistem informasi pengerjaan proyek berbasis web merupakan perancangan sistem informasi dengan menggunkan metode rapid application development (RAD) yang menawarkan solusi permasalahan sistem manual dengan beberapa keunggulan seperti memudahkan monitoring pengerjaan proyek dan pencarian history pekerjaan, menghilangkan duplikat dan meminimalisir kesalahan pembuatan invoice, meningkatkan kecepatan dan efisiensi penerimaan pengerjaan proyek sehingga performa kerja dapat ditingkatkan.

\section{DAFTAR PUSTAKA}

[1] R. Trimahardhika and E. Sutinah, "Pengguna Metode Rapid Application Development Daam Perancangan Sistem Informasi Perpustakaan," J. Inform., vol. 4, no. 2, p. 249, 2017, [Online]. Available: http://ejournal.bsi.ac.id/ejurnal/index.php/ji/article/view/2226.

[2] M. Zen, S. A. I. Hidayat, and E. H. Purwanto, "Sistem Informasi Maintenance Work Order Berbasis Web Studi Kasus Departemen Building Pt . Elangperdana Tyre Industry," Semin. Nas. Teknol. Inf. Univ. Ibn Khaldun, pp. 421-429, 2018.

[3] V. Pandey, A. Bairwa, and S. Bhattacharya, "Application of the Pareto principle in Rapid Application Development Model," Int. J. Eng. Technol., vol. 5, no. 3, pp. 26492654, 2013.

[4] N. Aini, S. Wicaksono, and I. Arwani, "Pembangunan Sistem Informasi Perpustakaan Berbasis Web menggunakan Metode Rapid Application Development (RAD) (Studi pada : SMK Negeri 11 Malang)," J. Pengemb. Teknol. Inf. dan Ilmu Komput., vol. 3, no. 9, p. 9, 2019, [Online]. Available: http://j-ptiik.ub.ac.id/index.php/jptiik/article/download/6236/2996.

[5] A. Waluyo and A. Munawar, "Perancangan Aplikasi Monitoring Penerimaan dan Pelaksanaan Proyek Berbasis Web dengan Metode Prototyping Pada PT. Fas Jawara," J. SISFOKOM, vol. 06, pp. 20-26, 2017.

[6] F. Abdussalaam and M. Mardiansyah Ramadhan, "Perancangan Sistem Informasi Work Order Dengan Metode Iteratif Menggunakan Framework Codeigniter (Studi Kasus :CV Sirna Miskin Bandung)," J. E-Komtek, vol. 3, no. 1, pp. 35-48, 2019, doi: 10.37339/ekomtek.v3i1.129.

[7] M. Badrul and N. S. Dewi, "Penerapan Metode Rapid Application Development untuk Perancangan Sistem Informasi Penagihan Piutang Premi Asuransi," J-SAKTI (Jurnal Sains Komput. dan Inform., vol. 4, no. 2, pp. 319-326, 2020.

[8] A. Febriani and N. Hidayati, "Penerapan Aplikasi Program Penjualan Dan Pembelian Menggunakan Model Rapid Application Development," J. Inform., vol. 4, no. 2, pp. 261-271, 2017.

[9] R. A. Sukamto and M. Shalahuddin, Rekayasa Perangkat Lunak (Terstruktur dan Berorientasi Objek). Bandung: Informatika Bandung, 2016.

[10] R. S. Pressman and B. Maxim, Software Engineering: A Practitioner's Approach 8th Edition. New York: McGrawHill Education, 2014. 